\title{
Debts and salaries tempt British graduates aw ay from research
}

[LONDON] Increasing numbers of UK graduates are turning away from postgraduate training, according to new government data. Engineering and the physical sciences are worst hit, with financial reasons apparently at the root of the recruitment problems.

Over the past three years, the proportion of unfilled masters' and $\mathrm{PhD}$ studentships offered by Britain's research councils has (see table). The Engineering and Physical Sciences Research Council (EPSRC) has the most empty places; this year 558 postgraduate training opportunities were unfilled.

Possible explanations include a healthy employment market, the low level of the $\mathrm{PhD}$ stipend, and the increasing debts of university graduates. EPSRC also points out that their figures do not include project studentships - PhDs offered as part of a research grant — whose numbers have been increasing over the last couple of years.

Money seems to be the key. "There is now a considerable difference between the stipend for research studentships and [graduate] starting salaries," comments David Schildt, Head of Cross Council Programmes at EPSRC.

Despite the recent $\mathfrak{E} 1,000$ (US $\$ 1,600$ ) rise in $\mathrm{PhD}$ stipends, which came too late to influence the majority of this year's students, more than doubled, from 4.8 to 11.0 per cent

\begin{tabular}{|c|c|c|c|c|c|c|}
\hline \multicolumn{7}{|c|}{ Unfilled postgraduate positions } \\
\hline & \multicolumn{2}{|c|}{ 1996-97 } & \multicolumn{2}{|c|}{$1997-98$} & \multicolumn{2}{|c|}{$1998-99$} \\
\hline & Offered & Unfilled & Offered & Unfilled & Offered & Unfilled \\
\hline BBSRC & 740 & 7 & 740 & 10 & 740 & 16 \\
\hline EPSRC & 3,782 & 219 & 3,725 & 376 & 3,814 & 558 \\
\hline MRC & 340 & 23 & 351 & 20 & 350 & 17 \\
\hline NERC & 544 & 13 & 538 & 3 & 546 & 6 \\
\hline Total & 5,406 & 262 & 5,354 & 409 & 5,450 & 597 \\
\hline
\end{tabular}

BBSRC, Biotechnology and Biological Sciences Research Council; EPSRC, Engineering and Physical Sciences Research Council; MRC, Medical Research Council; NERC, Natural Environment Research Council. The 1998-99 figures for BBSRC, EPSRC and MRC are provisional.

the current minimum annual pay is still only $\mathfrak{E} 6,500$. For PhD students, especially in engineering and physics, this is a fraction of their earning potential as graduates.

Swiftly rising levels of graduate debt - a new phenomenon in the United Kingdom due to the gradual reduction in government grants to undergraduates make it more difficult for graduates to ignore lucrative job offers. This is likely to get worse; last year saw the introduction of $\mathfrak{E} 1,000$ annual tuition fees.

The National Union of Students says that the mean debt of graduates is now between $\mathfrak{E} 4,000$ and $\mathfrak{E} 5,000$. This will worsen when the maintenance grant is removed at the end of 1999, when maintenance will be available only as loans. The union estimates that students starting university this year will leave

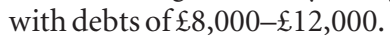

\section{Former Pasteur head defends politicians}

[PARIS] The prosecution's case against former prime minister Laurent Fabius in France's 'contaminated blood' trial appeared to have been further undermined last week by testimony from François Gros, scientific adviser to Fabius in the 1980s.

Gros, one of France's most eminent biologists and a former director of the Institut Pasteur, absolved Fabius of any wrongdoing and assumed "full responsibility" for the actions underpinning the prosecution's case against the former prime minister.

Along with two other former ministers, Fabius has been charged with involuntary homicide' for alleged negligence in handling the risk of the transmission of HIV in the blood supply in 1985 . The case against him rests mainly on the allegation that he delayed the introduction of a US test manufactured by Abbott Laboratories to protect the national market for a French test (see Nature 397, 548; 1999).

The central plank of this allegation is a decision taken at an interministerial meeting held in the prime minister's office
Another explanation is that the introduction of four-year undergraduate degrees with a strong research component is affecting the take-up of masters and $\mathrm{PhDs}$.

The figures for unfilled studentships do not include figures for the Particle Physics and Astronomy Research Council, which is currently carrying over unfilled studentships from year to year because of the impact of four-year degrees on take-up.

Unease over the recruitment of research students was raised at a recent EPSRC conference. Richard Brook, chief executive of EPSRC, said these concerns were "very much shared", adding that, with the current level of the $\mathrm{PhD}$ stipend, research may appear increasingly less attractive.

"There has been more difficulty this year in filling the awarded studentships," admits Brook. Universities have been concerned about the issue of poor postgraduate recruitment for some time.

Some subjects have been harder hit than others. One speaker at the conference said that, despite a 25 per cent increase in applicants for computer science undergraduate degrees at the University of Southampton, it was "very hard" to attract postgraduates into academia, and even harder to keep them once they had completed PhDs.

A breakdown of EPSRC figures shows a rise in unfilled studentships across all subject areas. Schildt says that there are plans to address this by "increasing dialogue" between university departments, employers and students. "Every studentship place unfilled is a lost opportunity," he says.

The unfilled studentships take on added significance in the light of EPSRC's keenness to be judged on the knowledge - rather than the technical innovations - that it produces. Last week, departing chairman Alan Rudge denounced what he described as the "invention mania" behind pressure on universities to increase financial returns on inventions and intellectual property rights, which currently yield less than 1 per cent of university revenue. Natas ha Loder See also the News Analysis on page 640. many factors, in particular costs to the healthcare system.
Declan Butler 